\title{
WAEMU's External Trade Efficiency: Measurement and Determinants
}

\author{
Zahore Gnoleba Martin \\ University Alassane Ouattara, Bouaké, Côte d'Ivoire
}

\begin{abstract}
This article examines the measurement and determinants of WAEMU's (West African Economic and Monetary Union) external trade efficiency. The sample includes eight countries and covers the period from 1990 to 2014. The study's estimations are based on data from the database WDI (World Development Indicators) of the World Bank and data from BCEAO with the view to answer to the central question posed. The study is also based on the approach of a gravity equation in panel then a stochastic frontier cost. The results suggest that the score of efficiency of WAEMU's external trade is very low on the one hand and the range and importing countries' GDP negatively influence this score while GDP of the exporting countries, the common border and common language positively influence the efficiency of external trade of that union. These results show that the different WAEMU's countries have an interest in establishing new trade and fiscal policies able to lead them on a long period on the path of self come growth.
\end{abstract}

Keywords: efficiency, external trade, gravity model, panel, development, growth

\section{Introduction}

Is external trade of WAEMU's countries efficiency or inefficiency, and what might be the determinants of that efficiency or inefficiency? When one refers to the old and the new theory of international trade, it is very clear that the interest that countries give to external trade is explained by its effects on both economic growth and social development (Krugman \& Obtefeld, 2010). Indeed since the theory of David Ricardo which explains exchanges between countries through comparative advantages, Adam Smith's theory that favors compulsory existence of absolute advantages for states in the conduct of world trade, and HOS theory which puts the emphasis on the differences in factor endowments between states to explain trade, external trade is seen as the best way of mobilizing currencies through imports and exports of goods of any kind. Furthermore the importance of external trade for all countries around the world has led the creation of several organizations and institutions in order to regulate and avoid the distortions of relative prices between which colaborate in exchange. So we move from GATT to WTO to allow these states to peacefully participate in trade of goods and services in an appropriate and adequate environment. However it should be noted that the effects of trade on growth are not perceived in the same way in the economic literature. Indeed, while for fans of protectionist trade openness can lead to negativity on economic growth, it is not the case for free trade supporters who agree

Zahore Gnoleba Martịn, lecturer, Department of Economics and Development, University Alassane Ouattara, Bouaké, Côte d'Ivoire.

Correspondence concerning this article should be addressed to Zahore Gnoleba Martin, Department of Economics and Development, University Alassane Ouattara, 01 BP V18 Bouaké 01, Côte d'Ivoire. 
that participation in globalization is a source of gain of productivity and also of development (Mucchielli, 1989). But in any event, it should be noted that beyond all these doctrinal controversies, an efficience exetrnal trade is certainly guarantee of development. That said the aim of this study is to empirically measure the level of efficiency or inefficiency of external trade in WAEMU's countries and to bring to light the determinants respectively. Specifically if this analysis does not presuppose a preset inefficiency of external trade of that economic and monetary union, it is intended as a framework for discussing and recommending about economic policy to ensure a dynamic external trade to WAEMU's countries and also lead them to take an active part in world trade because actually the part of Africa in world trade is low. The study uses the technique of gravity model to estimate a panel border, in order to determine the level of efficiency or inefficiency and finally to bring to light the determinants of the efficiency or inefficiency. The rest of the study is as follows: the literature review will be the subject of the Section 2. The data description and definition of the variables used in this study will form the frame of the Section 3. In addition the presentation of the methodology will be done in Section 4 and in Section 5, the presentation of results will follow. Section 6, will focus on the conclusion and the implication of economic policies.

\section{Literature Review}

The consensus broken out from the theoretical literature is that trade promotes growth and poverty reduction, because it acts as a vehicle which allows exchanging the surplus of national production against the products of the other countries. Trade also encourages allocate resources based on comparative advantages of countries participating in the exchange and it stimulates the economic growth. These countries win from their exchanges some substantials gains in terms of prosperity. However, if the trade between the countries can lead to overall growth, there is no guarantee that the cumulative benefits are distributed equally between trading partners. There are both winners and losers in any business relationship. It is possible that participants in the trade are all winners, to varying degrees. Several factors determine the extent in which a country can take advantage from a business relationship. Among these factors they are the terms of trade between the country and its trading partners, the rate of the international exchange between the sold products and the features on the markets for products exported by the country. Winters (2002) demonstrated that trade can influence poverty through various ways (economic growth, evolution of the product's prices, sales revenue in the market, government revenues). Because poverty is the greatest challenge that Africa faces, the analysis of the link between trade and poverty has a crucial importance, because reducing the effects of poverty is one of the main goals. Many African countries still apply trade liberalization policies that would lead them to prosperity and growth, and allow them to eventually reduce poverty. Baldwin (2003), demonstrated convincingly that in countries where there are few restrictions to trade, the economic growth is faster than the economic growth of countries where more restricted policies are applied.

As poverty is reduced more rapidly when growth is faster, poor countries could use trade liberalization as an instrument of their policies. Trade liberalization reduces the relative price distortions and allows the activities with comparative advantages to get developed for boosting economic growth. Winter, McCulloch, and McKay (2004), show that it is possible to reduce poverty thanks to a long-term economic growth. They argue that a fast economic growth helps to raise income levels, which in turn, enables the government to collect more tax revenue to take distributive measures. To understand these effects, it is important to distinguish the link between openness of an economy and the growth on the one hand, the link between growth and inequality 
on the other. The theory that trade is positively correlated with economic growth is from Adam Smith, who argued that trade allows an increased specialization. Specialization allows reaching quickly to economies of scale, particularly for countries which have only domestic markets. All ways of production of a country are also fully exploited through trade. Domestic companies are forced to improve their technologies because of competition from imports. In addition, closed economic integration with the outside world fosters innovation through the diffusion of new technologies from more advanced countries. The link between trade and growth can result in an increased productivity of the diffrents factors. Contact with the worldwide market consolidates the total factor of productivity in an agricultural product. Agriculture is a sector where technical progress has been extremely important. This was demonstrated by the Green Revolution in Asia, with the improved practices and new varieties of seed that have been adopted. In Brazil also, this reality has been demonstrated with the spread of genetically modified crops. These ameliorations would not have occurred if these countries had not got in touch with the world markets. According to Krugman and obstefeld (2003), the history shows that poor countries that were able to improve the living standards of their populations have achieved this thanks to globalization, because they have chosen to produce for the world market rather than seek to be sufficient in themselves. Grossman and Helpman (1994), show that the integration into the world economy can boost productivity of a country. Firstly, residents of a country integrated into global markets can get access to technologicals knowledges in the contrary of those countries which live in relative isolation, because trade contributes to the diffusion of technology. Secondly, the exposure to international competition may lessen the risk of industrial research which is a difficult job. If a company that makes a product for the domestic market must use that technology, new only in the local economy, the one that hopes to successfully enter into the competition imposed by the international market will be forced to find really innovative ideas on a global scale. Thirdly, by expanding the potential customer base, international integration may encourage further industrial research.

Some economists use neoclassical models, which are essentially general equilibrium models with a scale of constant or decreasing returns, individuals acting rationally only by resorting to markets and without transaction costs. In such cases, the structure of trade between countries is determined by comparative advantages. Other economists use Ricardo's models in which comparative advantage is in the form of technological differences. In the Heckscher-Ohlin's model, comparative advantage takes the form of differences in resource endowments. The result which is achieved with the neoclassical models is that a country will get static gains from trade liberalization, because the most important of these is the efficiency gains in resource allocation. By lowering trade barriers, a country faced international relative prices that induce an efficiency in the allocation of domestic resources to areas showing a comparative advantage, increasing overall prosperity. However, Rodrik (1988), Devarajan and Rodrik (1989), and Krugman (1994) have questioned these results, arguing that neoclassical models retain only the increases of the incomes level and that trade liberalization can not lead to a sustainable increase of the growth rate. They argue that under the conditions characterized by economies of scale and imperfect competition, the effect of trade liberalization on the general prosperity can be negative. By using the endogenous model, Duncan and Quang (2003) explain that developing countries adopting protectionist policies which prevent the access to imported goods that contain improved technology are bad for the prospects of sustainable growth. The two authors argue that there are trade implications, including the diffusion of new knowledge, allowing improving the efficiency, and boosting a sustainable growth. The empirical evaluation of the relationship between trade and growth is inconclusive. 
Some studies have led to a positive correlation between trade and growth, while others have come to the conclusion that the reduction of trade barriers produces a negative effect.

Little, Scitovski, and Scott (1970) and Balassa (1971) were the first to focus on the subject. From that day, many economists have tried to establish a link between variables of trade policy and the results of economic growth. The search company can be divided into two groups: studies of several countries, which analyze in detail the experience of some countries that have conducted trade reforms; and comparative empirical studies covering several countries, in which the relationship between the openness of the economy and trade is analyzed. Initial studies, undertaken by Dollar (1992), Sachs and Warner (1995), Ben-David (1993) and others, have consisted of comparative analyses of regression covering several countries. They have found positive correlations between the degree of openness of a country and the speed of economic growth. However, Rodriguez and Rodrik (1999) and Rodrik (2001) have questioned these results, deducing that the opening is probably a consequence rather than a precondition for growth. To address the issue of causality, Frankel and Romer (1999) only analyze the effect of the component of the trade which can not be influenced by short-term growth, mainly attributable to the population, the occupation of the territories concerned and distances. They note that this component accounts for a significant proportion of the differences between countries in terms of income and growth, and suggest that there is a general relationship between a greater volume of trade and stronger growth. Dollar and Kraay (2002) have also shown the existence of a link between trade liberalization and the reductions of levels of poverty through growth. Salinas and Aksoy (2006), use the estimate from the country which is under study to bypass the need to measure the degree of trade openness and they reached the conclusion that, on average, GDP growth per capita increased from $1.2 \%$ to $2.6 \%$ after a trade liberalization. It can be concluded from these studies that trade reforms contribute to a sustainable economic development in developing countries. Moreover, trade liberalization has a positive influence on the efficiency and the long-term stability. According to Winters et al. (2004), three difficulties can be encountered when we try to establish an empirical link between trade and economic growth. Firstly, for countries that do little or no trade with the outside world, it is very difficult to measure the state of their trade. Secondly, trade liberalization alone does not guarantee a lasting effect on the growth. It must be combined with other structural policies. Thirdly, it is very difficult to establish the link of causation. Trade policy reforms and strategies are the basis for sustainable growth experienced by a number of countries. Watson (2000) argues that for low-income countries with low trade institutions, industrial free zones can be effective instruments for promoting production for export, not only because they allow access in right free to some factors of imported products, but also because they are ways of facing the problem of infrastructure as well as the weakness and public services which stops investment.

In an analysis about more than 50 empirical studies, Matusz and Tarr (1999), however, concluded that the adjustment costs are minimal compared to the benefits of trade liberalization.

Moreover, according to a study of trade reforms in 19 developing countries, Papageorgiou, Choksi, and Michaely (1990) concluded that trade liberalization did not lead to, in general the reduct of employment, even in the short term. These authors found that, compared with the period before the reform, employment in manufacturing was becoming more important one year after the liberalization. In fact, in 12 or 13 cases, employment in manufacturing was becoming more important during the reform period compared to levels recorded before the liberalization. Parker, Stradling, and Manstead (1995) and Harrison and Revenga (1995), conducted some similar studies that led to the same results. In the $70 \mathrm{~s}$, a number of developing countries have 
started to liberalize their trade and sought to open their economies to global markets. As Baldwin (2003) has pointed it out, these policies, known as "import-substitution industrialization" were based on two assumptions: the need to address the widening gap between rich countries and poor countries, because of the absence of industries in developing countries; to get industrialized, small countries should protect their new manufacturing sector. These ideas have had a real influence, particularly in Latin America and some African countries. Kruger (1998) indicates that it is in the late 80s that protectionist policies began to lose ground. Developing countries had waived the import substituting industrialization in favor of the alternative to exports, which requires trade liberalization. As for Dollar and Kraay (2001), they show an increase in the part of trade in GDP is a solid indication of openness in trade policy. They also show in their study that developing countries which have reformed their trade policies towards greater trade openness achieved a rise of $2.9 \%$ in their growth rate in the 70 s to $3.5 \%$ in the years 80 , and $5 \%$ in the 90 s.

Further, Sachs and Warner (1995) examine the growth outcomes as a function of trade policy and other variables (investment rate, percentage of GDP devoted to public spending, education and number of revolutions and political coups) for 79 countries during the period between 1970 and 1989. They first performed some regressions by linking growth in terms of real per capita income over the period of initial per capita income, a binary variable that indicates if the economy was "open" during the whole period, to know the investment rate, the relative price of capital goods, public consumption expenditure relative to the GDP and a whole series of variables concerning the political stability. The results they have achieved show a statistically significant coefficient showing open trade, which indicates that during the two decades studied, real income per capita increased by 2.2 percentage points faster in economies open than in closed economies.

Then Wacziarg and Welch (2003), grow further analysis of Sachs and Warner's by passing from the sample to time series and then to expert analysis. They reproduce and update the extent of the opening of Sachs and Warner and confirm the conclusion of the latter that trade liberalization has a positive effect on growth. Wacziarg and Welch (2003) set the date of opening the trade regime for each of the 133 countries and notice that the growth in countries which have opted for trade liberalization was, during the period following the opening on average $1.4 \%$ higher than in the pre-liberalization period. Jin (2004) analyzed the co-movement between openness and growth for China's 17 provinces and three municipalities. The author wanted to check if the relationship openness growth was also valid at the provincial level, and if we could detect a difference between the coastal provinces (seven in number) and those isolated (numbering 13). He built his model on the usual production function, including technological change, which itself depends on the degree of openness of the country. The results obtained are those expected: the effect for coastal provinces is significant and positive sign for four of them, and negative for the majority of landlocked provinces (three of them have a negative and significant effect). The explanation which is brought out is that the provinces without access to the sea do not have a strong enough economy to face the foreign competition, while coastal provinces are already oriented economies outside, and therefore more competitive.

As we notice it no study has yet really addressed the empirical evaluation of the level of efficiency or inefficiency of external trade in WAEMU's countries, at least, the identification of determinants of the efficiency or inefficiency of external trade in the said countries. The present analysis is therefore intended not only to measure the contribution of external trade of the WAEMU's countries, but also especially to identify the determinants of the efficiency or inefficiency of the external trade of countries members of the West African Economic and Monetary Union. 


\section{Description of Data and Definition of Variables}

The analysis covers the eight (8) WAEMU (West African Economic and Monetary Union) countries and covers the period 1990-2014. This is a homogeneous panel data. This study is based on data from the database WDI (World Development Indicators) of the World Bank and data BCEAO. To try to answer the central question posed, the key variables used are as follows and they are natural logarithm.

\begin{tabular}{|c|c|c|}
\hline Variables & Definitions & Expected sign \\
\hline$X_{i j}\left(M_{i j}\right)$ & $\begin{array}{l}\text { Is exports (imports) of country } \mathrm{j} \text {, that is the } \log \text { of exports of country } \mathrm{i} \text { to } \\
\text { country } \mathrm{j} \text {. }\end{array}$ & Explained variable \\
\hline $\log _{\text {GDP}} /$ Head $_{i}$ & $\begin{array}{l}\text { This is the natural logarithm of per capita GDP of country } i \text { and measures the } \\
\text { level of development of this country. }\end{array}$ & Positive \\
\hline $\log$ GDP/Head ${ }_{j}$ & $\begin{array}{l}\text { This is the natural logarithm of per capita GDP of country } \mathrm{j} \text { and measures the } \\
\text { level of development of this country. }\end{array}$ & Positive \\
\hline $\log \left(\mathrm{GDP}_{\text {real }} /\right.$ head $\left._{i}\right)$ & Real GDP is the log of country $i$. & Positive \\
\hline $\log \left(\mathrm{GDP}_{\text {real }} /\right.$ head $\left._{j}\right)$ & Represents the log of real GDP of country $j$. & Positive \\
\hline $\log \left(\mathrm{DIST}_{i j}\right)$ & $\begin{array}{l}\text { Represents the logarithm of the geographical distance of the capital of country } \\
\text { i to the capital of country j. It is an approximation of the cost of transport; } \\
\text { because transportation costs are usually picked up by the distance between the } \\
\text { coechangistes (Avom \& Gbetnkom, 2005, p. 90). }\end{array}$ & Negative \\
\hline$\left(\mathrm{FRON} \mathrm{COM}_{i j}\right)$ & $\begin{array}{l}\text { Dummy variable representing the common border between countries i and j, it } \\
\text { is } 1 \text { if yes and } 0 \text { otherwise. The border effect of trade measures in a way the } \\
\text { distance left to go to achieve, within an economic union, the reference level } \\
\text { integration that exists within the countries. }\end{array}$ & Positive \\
\hline$($ P.LANG.COM $i j)$ & $\begin{array}{l}\text { Dummy variable representing the first common language between countries i } \\
\text { and j. This variable provides information aboutthe colonial past and we retain } \\
\text { it in our study because the authors like Anderson and Van Wincoop (2004), } \\
\text { Frankel and Rose (2002) showed its role in trade. }\end{array}$ & Positive \\
\hline
\end{tabular}

\section{Econometrics Methodology.}

The estimated model is usually linear, and it is of the form:

$$
\begin{gathered}
X_{i j}=\mathrm{A} \times G D P_{i}^{\alpha_{1}} \times G D P_{j}^{\alpha_{2}} / \operatorname{DIST}(i j)^{\alpha_{3}} \\
\log \left(X_{i j}\right)=\log \left(A \times G D P^{\alpha_{1}} \times G D P^{\alpha_{2}} / D I S T(i j)^{\alpha_{3}}\right)
\end{gathered}
$$

Alternatively,

$$
\log \left(X_{i j}\right)=\log \left(\propto_{0}\right)+\propto_{1} \times \log \left(G D P_{i}\right)+\propto_{2} \times \log \left(G D P_{j}\right)-\alpha_{3} \times \log \left(D I S T_{i j}\right)+\varepsilon_{i j}
$$

where $\varepsilon_{\mathrm{ij}}$ is replaced (added) by the surface area, population and dummy variables such as colonial history, language, GDP/head relating to swingers country. This model is inspired by Siroën, Duc, and Lavallee (2008). After reparameterization of the original model, we obtain the final model which is the following:

$$
\begin{aligned}
\log \left(X_{i j}\right)=\log & \left(\propto_{0}\right)+\propto_{1} \times \log \left(G D P_{\text {real } i}\right)+\propto_{2} \times \log \left(G D P_{\text {real } j}\right)+\propto_{3} \times \log \left(G D P_{\text {Real } / \text { headi }}\right)+\propto_{4} \\
& \times \log \left(G D P_{\text {real } / \text { headj }}\right)+\log \left(D I S T_{i j}\right)+\propto_{6} \times \log \left(L A N G_{-} C O M_{i j}\right)
\end{aligned}
$$

where: $\mathrm{I}$ is the exporting and $\mathrm{J}$ the importing country in the WAEMU zone and is a variable that captures the residue $\mathrm{I}$ in the country $\mathrm{J}$ at time $\mathrm{t}$; it is distributed according to a log-normal rule with is a constant. $\alpha_{1}, \alpha_{2}, \alpha_{3}, \ldots . \alpha_{n}$ are the coefficients whose signs are directories on the interpretation of the effects that each is supposed to express according to the relationship between the explained variables and explanatory variables respectively.

Before proceeding to the estimation of the border, we represent five fundamentals equations for further work. 
Traditionally, the gravity model is estimated by the OLS based on the assumption that the actual values and predicted values of the differences are purely random.

$$
Y_{i j, t}=f\left(X_{i j, t}\right)+\varepsilon_{i j, t}
$$

where $\varepsilon_{i j, t}$ is the disturbance term and is assumed to be independent and identically distributed, (iid), $X_{i j, t}$ is the vector of variables mentioned above, and $\mathrm{f}\left(X_{i j, t}\right)$ is the predicted value of the bilateral trade. So we consider that the value of the predicted external trade deviates from its true value by a random value that is zero and it has both negative and positive value that can be justified by error and other measures.

Under assumption of stochastic frontier estimation, the error term is decomposed into two parts:

$$
\varepsilon_{i j, t}=v_{j, t}-u_{i j, t}
$$

so the equation (1) becomes

where

$$
Y_{i j, t}=f\left(X_{i j, t}\right)+v_{j, t}-u_{i j, t}
$$

$$
v_{i j, t} \sim \text { iid } \mathrm{N}\left(0, \sigma_{v}^{2}\right)
$$

and

$$
u_{i j, t} \sim \text { iid } \mathrm{N}\left(0, \sigma_{u}^{2}\right)
$$

The term error $v_{i j, t}$ is the normal statistical noise due to luck or measurement error, while the error term one-way $u_{i j, t}$ is the measure of the performance or, in the case of production functions, the degree to which the difference between actual output and potential output is given by the stochastic frontier equation (2). The non-negative $u_{i j, t}$ in equation (2) represents the "efficiency" of a country in its external trade resulting from the lack of adequate infrastructure or the lack of management expertise.

According to Jondrow, Lovell, Materov, and Schmidt (1982), technical efficiency for each observation is $\mathrm{E}\left[u_{i j} / \varepsilon_{i j}\right]$, given the estimation of residues in equation (2) for $\varepsilon_{\mathrm{ij}}$ from the stochastic frontier method. In particular, from the stochastic frontier estimation (2), we estimate $\sigma_{v}^{2}$ and $\varepsilon_{i j}$. The estimate of the error term, $\varepsilon_{\mathrm{ij}}$ is the residue. Of the estimate, the following quantities can be calculated: $\sigma^{2}=\sigma_{v}^{2}+\sigma_{u}^{2}$.

From these estimates, we have the technical efficiency of each observation which can be calculated with this equation:

$$
T E_{i j, t}=\exp \left(\left(-\sigma_{v}^{2} \sigma_{u}^{2} / \sigma\right)\left[\frac{\varphi\left(u_{i j, t}\right)}{1-\varphi\left(u_{i j, t}\right)}-u_{i j, t}\right]\right)
$$

\section{Estimation of the Border}

At this level, it is the above equation, it means the estimated gravity equation which is reconsidered. OLS model residues by estimating the gravity equation with fixed effects. The resulting residues are interpreted as follows: positive residues indicate that the level of trade predicted by the gravity equation is below the current trade level; and vice versa for some negative residuals, we note that the external trade predicted level is above the trade currently observed.

The estimate of the border is also done by the stochastic method. It quantifies the efficiency of trade taking account of distances and predicted trade flows. The stochastic frontier estimation is used for the functions of production and cost functions. As the gravity equation is considered as the result of the minimization of transaction costs or transportation in international trade, the estimation of the stochastic frontier is relevant and appropriate for the gravity equation, measuring business efficiency. 
The estimated gravity model being affected by stochastic frontier method, calculations efficiencies are performed by the equation (5) mentioned above. These efficiencies are calculated for each observation.

\section{Estimation of a Gravity Equation in Panel}

To find the determinants, literature offers us a number of variables. While considering the gravity model of part 1 and believing in the panel, we can see how these different variables influence external trade.

This model is:

$$
\begin{aligned}
\log \left(X_{i j}\right)= & \log \left(\propto_{0}\right)+\propto_{1} \times \log \left(G D P_{\text {reali }}\right)+\propto_{2} \times \log \left(G D P_{\text {realj }}\right)+\propto_{3} \times \log \left(G D P_{\frac{\text { reall }}{\text { headi }}}\right)+\propto_{4} \times \\
& \log \left(G D P_{\frac{\text { reall }}{\text { headj }}}\right)+\log \left(D I S T_{i j}\right)+\propto_{6} \times \log \left(L A N G_{C O M_{i j}}\right)
\end{aligned}
$$

This is done in two parts. Administered one hand, the Hausman test consists of verifying the origin of the panel data and allows setting us on the choice of model to adopt for the estimation. It is a fixed or random effects model. And secondly we proceed to the actual estimation of actual model.

\section{Empirical Results}

This section will serve to the presentation of the results of the differents econometrics estimations conducted in this study. We begin by presenting the results of the estimation of the gravity model.

Table 1

Estimated Gravity Model

\begin{tabular}{lllll}
\hline Variables & \multicolumn{2}{c}{ OLS estimates } & \multicolumn{2}{c}{ Frontier estimates } \\
\cline { 2 - 5 } & Coeff & $p$ value & Coeff & 0.22 \\
\hline LGDP i & 2.25 & 0.00 & 2.21 & 0.06 \\
LGDP j & 0.74 & 0.00 & 0.70 & 0.01 \\
Ldist & -1.14 & 0.03 & -1.01 & 0.00 \\
LGDP/head i & 0.70 & 0.01 & 0.65 & 0.05 \\
LGDP/head j & -0.43 & 0.00 & -0.40 & 0.04 \\
Dummy language & 1.70 & 0.00 & 1.65 & 0.11 \\
Dummy frontier & 2.32 & 0.00 & 2.30 & \\
$\mathrm{R}^{2}$ & 0.72 & & &
\end{tabular}

Source: Our calculations.

Table 1 provides us with the results of the estimation of the gravity equation by ordinary least squares method and the results of the estimation of the border by the maximum likelihood method. In the analysis, all variables have the expected signs except the variable $L G D P /$ head $j$ while their significance varies the gravity model to the stochastic frontier. An explanation of the unexpected sign of the variable LGDP/head $j$ which summarizes the level of economic growth of the importing country could be the following: when an importing country has a low level of development compared to its partners in the exchange in the same union, that country can properly participate in the dynamism of trade seen by hypothesis it is supposed to be poorer and therefore it will not happen ceteris paribus to set up the charges inherent in imports. Moreover, we can also argue that a scenario like that is the result of the presence of rigidities in the trade policy of the country and the lack of adequate commercial structures.

In sum, Table 1 allows us to see that external trade in the WAEMU zone is generally doing well. 
After estimating the gravity equation, and stochastic frontier we can now move on to determining the level of efficiency of foreign trade in the WAEMU zone. These results are given in Table 2.

Table 2

Measuring the Effficiency of Foreign Trade

\begin{tabular}{lll}
\hline Pays & Eff & OLS \\
\hline Benin & 0.25 & -0.12 \\
Burkina & 0.23 & -0.14 \\
Côte d'Ivoire & 0.32 & 0.32 \\
Guinée-Bissau & 0.30 & 0.45 \\
Mali & 0.25 & -0.23 \\
Niger & 0.21 & -0.36 \\
Senegal & 0.23 & -0.09 \\
Togo & 0.29 & 0.67 \\
UEMOA & 0.25 & -0.23 \\
\hline
\end{tabular}

Source: Our calculations.

The results in this table tell us that the level of the efficiency of foreign trade at the WAEMU level is $25 \%$. In other words, external trade of WAEMU is inefficient and its degree of inefficiency is $75 \%$; in addition all members of this union have substantially the same degree of efficiency with very low average of $22 \%$. However, this low level of efficiency in the WAEMU zone should not hide the possibility for its members to make their most dynamic trade flows and hence more efficience. Indeed the values in the third column of Table 2 indicate if they are positive that the average real trade flows are larger than the predicted values indicating when the external trade is efficience. It therefore follows from this reasoning that Côte d'Ivoire, Guinea Bissau, and Togo have an efficient external trade on the contrary of Burkina Faso, Mali, Niger, and Senegal.

In short, the estimate of foreign trade of the WAEMU zone by the gravity model on the one hand and the technique of stochastic frontier on the other hand allowed us to calculate the efficiency scores for each observation in our sample. We considered effective as a measure of the average for the eight (8) countries on the actual number of observations in all given. It should now move to the identification of determinants of efficiency. But before estimating the determinants, we need to administer the test Hausman.

Table 3

Hausman Test Results

\begin{tabular}{lllll}
\hline & (b) & (B) & (b-B) & sqrt(diag(V_bV_B)) \\
& Fixed & Random & Difference & S.E. \\
\hline $\operatorname{lgdp\_ i}$ & 4.37263 & 2.256443 & 2.116186 & 0.3993528 \\
$\operatorname{lgdp\_ j}$ & 2.58575 & 0.7394853 & 1.846265 & 0.4507762 \\
$\operatorname{lgdp\_ par\_ t~i~}$ & -1.082353 & 0.6995226 & -1.781876 & 0.2913963 \\
$\operatorname{lgdp\_ par\_ t\sim j}$ & -2.034591 & -0.4341697 & -1.600421 & 0.4715343 \\
\hline
\end{tabular}

Note. Prob. $>$ chi $2=0.0000$. Source: our calculations.

Table 3 above shows the results of the test Hausman. We administered the test to discriminate between the random effects model and fixed effects model. The results show that the estimation with fixed effects model seems the most appropriate. But given that certain variables such as distance and the common language do not depend on time, we chose the random effects model to estimate them. 
After the Hausman test we will go now to the estimation of gravity modeling on the panel.

Table 4

Result of the Estimation of the Gravity Model With Panel

\begin{tabular}{lllll}
\hline Variables & Coef. & Std. err. & Z & $p$ value \\
\hline lgdp_i & 2.256443 & 0.2871686 & 7.86 & 0.000 \\
lgdp_j & 0.7394853 & 0.1208251 & 6.12 & 0.000 \\
Ldistw & -1.139159 & 0.197826 & $-5,76$ & 0.000 \\
lgdp_per_head_i & 0.6995226 & 0.2662769 & 2.63 & 0.009 \\
lgdp_per_head_j & -0.4341697 & 0.1236783 & -3.51 & 0.000 \\
comlang_off & 1.708936 & 0.4444672 & 3.84 & 0.000 \\
_cons & -21.09341 & 2.738388 & -7.70 & 0.000 \\
\hline
\end{tabular}

Source: Our calculations.

The results of the estimation of the gravity model with panel allow us to notice that determinants of the efficiency of the foreign trade of WAEMU can be classified in to two main groups: one the one hand, we have some variables which influence positively the score of efficiency of the foreign trade not only of each country but also mainly of the entire zone. Those variables are the following: the common border between the states, the common language, and GDP (Gross Domestic Product) of the exporter country. On the other hand, we have the variables which act passively or negatively on the scores of the efficiency of the foreign trade of countries from WAEMU and also on each country of the union. We can take as example the distance between the exchanger countries and the GDP per head of the importer country.

\section{Conclusion and Implication of Economic Policies}

The aim of our study was to empirically measure the efficiency of external trade in WAEMU'S countries and to bring to light its determinants. For this purpose we used the methodology of the gravity model and the stochastic frontier to reach our purposes. Our results reveal that whatever the conutries studied individually or WAEMU zone as a whole score of efficiency of external trade remains very low even if it is possible for those nations to make their trade flows more dynamic and therefore more efficient. To do that, we recommend WAEMU's countries to work for achieving the convergence of living standards of their peoples; to work for the establishment of strong institutions, road infrastructure, and adequate business structures with the goal of reducing transportation costs owing to the remoteness of the different capitals. Furthermore the WAEMU'S countries must provide new community-based mechanisms for the settlement of trade disputes while not failing to make it more dynamic than the current mechanisms.

\section{References}

Anderson, J. E., \& Wincoop, E. V. (2004). Trade costs. Journal of Economic Litterature, XLII (September 2004), 691-751.

Aigner, D. J., Lovell, C. A. K., \& Schmidt, P. (1977). Formulation and estimation of stochastic frontier production function models. Journal of Econometrics, 6, 21-37. doi: 1016/0304-4076(77)90052-5

Asia pacific Economics Group (APEG). (1998). Asia Pacific profiles, financial times (finance), Hong Kong.

Avon, D., \& Gbetnkom, D. (2005). L'Intégration par le Marché: Le cas de l’UEMOA. Région et Développement, $22-2005$.

Balassa, B. (1971). The structure of protection in developing countries. Baltimore, MD: Johns Hopkins University Press. doi: $10.2307 / 1238366$

Baldwin, R. (2003). Openness and growth: What's the empirical relationship. NBER Working Paper 9578, 2003. doi: $10.3386 /$ w9578 
Barro, R., \& Sala-i-Martin, X. (1995). Economic growth. New-York: Mc Graw Hill. doi:10.1016/s0165-1889(97)00007-9

Ben-David, D. (1993). Equalizing exchange: Trade liberalization and income convergence. Quarterly Journal of Economics. doi: $10.2307 / 2118404$

Breush, T. S., \& Pagan, A. R. (1979). A simple test for heterocedasticity and random coefficient variation. Econometrica, 47, 1278-1294.

Devarajan. S., \& Rodrik, D. (1989). Pro-competitive effects of tariff reform. Working Paper, J. F. Kennedy school, Harvard University.

Dollar, D., \& Kraay, A. (2002). Growth is food for the poor. World Bank Policy Research Working Paper, 2002.

Dollar, D. (1992). Outward oriented developing economies really do grow more rapidly: Evidence from 95 LDCs. Economic Development and Cultural Chang. doi: 10.1086/451959

Drysdale, P., \& Grenaut, R. (1982). Trade intensities and the analysis of bilateral trade flows in a many country world: A survey. Hitotsubashi Journal of Economics, 22(2), 62-84. doi:10.15057/7939

Duncan, R., \& Quang, D. (2003). Trade liberalization, economic growth and poverty reduction strategies. National Centre for Development Studies, The Australian National University.

Farrell, M. J. (1957). The measurement of productive efficiency. Journal of the Royal Statistical Society, Series A, 120, 253-281.

Frankel, J. A., \& Romer, D. (1999). Does trade cause growth? American Economic Review. doi: 10.1257/aer.89.3.379

Frankel, J. A., \& Rose, A. K. (2002). An estimate of the effect of common currencies on trade and income. Harvard University, Faculty Research. doi: 10.3386/w7857

Grossman, G. M., \& Helpman, E. (1994). Protection for sale. American Economic Review, 84(4), 833-850.

Gwartney, J. D., \& Lawson, R. A. (1997). Economique freedom of the world: 1997 annual report. The Faser institute, Vancover.

Harrison, A., \& Revenga, A. (1995). The effects of trade policy reform: What do we really know? National Bureau of Economic Research. doi: 10.3386/w 5225

Jin, C. J. (2004). On the relationship between openness and growth in China: Evidence from provincial time series data. The World Economy, 27(10), November.

Jondrow, J., Lovell, C. A. K., Materov, I. S., \& Schmidt, P. (1982). On the estimation of technical inefficiency in the stochastic frontier production function model. Journal of Econometrics, 19(1982), 233-238.

Kalirajan, K. (1999). Stochastic varying coefficients gravity coefficients gravity model: An application in trade analysis. Journal of Applied Statistics, 26(2), 185-194.

Kruger, A. (1998). Why trade liberalization is good for growth? Economic Journal. doi: 10.1111/1468-0297.00358

Krugman, P. (1991). The move toward free trade zones, in policy implication of trade and currency zones. Federal Reserve Bank of Kansas, Jackson Hole, Wyoming, August.

Krugman, P., \& Obtefeld, M. (2010). International economy, new horizons (8th ed.).

Krugman, P. R. (1994). Myth ofAsia's miracle. The Foreign Affairs, 73(November/December), 62.

Krugman, P. R., \& Obstefeld, M. (2003). Economie internationale. De boeck, 2003-2858.

Little, I., Scitovski, T., \& Scott, M. (1970). Industry and trade in some developing countries. Oxford University Press. doi: $10.2307 / 2229769$

Lucas, R. E. (1988). On the mechanics of economic development. Journal of Monetary Economics, 22(1). doi:10.1016/0304-3932(88)90168-7

Matusz, S. J., \& Tarr, D. G. (1999). Adjusting to trade policy reform (Vol. 2142). World Bank Publications.

Mucchielli, J. L. (1989). Principes D’économie Internationale. Ed économica.

Mucchielli, J. L. (1987). Multinational entreprises, international investisment and transfert of technology: The element of an integrated approach. In A. E. Safarian and G. Y. Bertin (Eds.), op.cit, 11-33.

Parker, D., Stradling, S. G., \& Manstead, A. S. R. (1995). Modifying beliefs and attitudes to exceeding the speed limit: An intervention study based on the theory of planned behaviour. Journal of Applied Social Psychology, 26, 1-9.

Papageorgiou, D., Choksi, A. M., \& Michaely, M. (1980). Liberalizing foreign trade in developing countries: The lessons of experience. The World Bank-Documents \& Reports.

Rodriguez, F., \& Rodrik, D. (1999). Trade policy and economic growth: A skeptic's guide to the cross-national evidence. NBER Working Paper.

Rodrik, D. (1988). Closing the technology gap: Does trade liberalisation really help? Working Paper No. 2654. National Bureau of Economic Research 1050. Massachusetts Avenue Cambridge, MA 02138, July.

Rodrik, D. (2001). The global governance of trade as if development really mattered. United Nations Development Programme. 
Sachs, J., \& Warner, A. (1995). Economic reform and the process of global integration. Brookings Papers on Economic Activity. Salinas, G., \& Aksoy, A. (2006). Growth before and after trade liberalisation. World Bank Policy Research Working Paper.

Siroen, J. M., Duc, C., \& Lavallee, E. (2008). The gravity of institutions. Economie Internationale, 113(2008), 95-113.

Tinbergen, J. (1962). Shaping the world economy, suggestions for an international economic policy. Twentieth Century Fund, New York.

Wacziarg, R., \& Welch, K. H. (2003). Trade liberalization and growth: New evidence. NBER Working Paper 10152 (Cambridge: National Bureau of Economic Research).

Watson, J. (2000). Via negative: Considering caring by way of non-caring. The Australian Journal of Holistic Nursing, 7(1), 4-8.

White, J. (1993). Shazam econometric computer programm: User's reference manual (7th ed.). New York: McGraw-Hill Book Company.

Winters, L. A. (2002). Trade liberalization and powerty: What are the links? World Economy, 25-1339-1367. doi:10.1111/1467-9701.00495

Winters, L. A., McCulloch, N., \& Mckay, A. (2004). Trade liberalization and poverty: The evidence so far. Journal of Economics Literature. doi: 10.1257/002205104773558056 